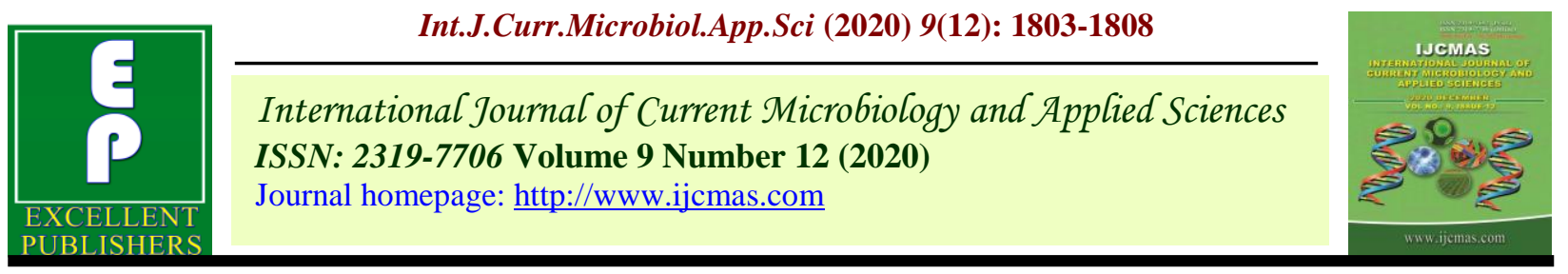

\title{
Effect of Zeolite on Nutrient Use Efficiency in Soil and Nutrient Uptake of Kharif Upland Paddy Grown on Inceptisol
}

\author{
T. S. Shinde ${ }^{1 *}$, R. B. Pawar ${ }^{2}$, A. V. Satpute ${ }^{3}$ and S. M. Shende ${ }^{3}$ \\ ${ }^{1}$ Division of Soil Science and Agricultural Chemistry, ${ }^{3}$ Division of Agronomy, \\ RCSM College of Agriculture, Kolhapur, Mahatma Phule Krishi Vidyapeeth Rahuri, \\ Maharashtra (India) \\ ${ }^{2}$ Agriculture Research Station, Kabse Digraj, Sangli, Maharashtra, India \\ *Corresponding author
}

\begin{tabular}{l} 
K e y w o r d s \\
Nutrient uptake, \\
Nutrient use \\
efficiency, Yield, \\
paddy, \\
Clinoptilolite \\
zeolite \\
\hline Article Info \\
Accepted: \\
14 November 2020 \\
Available Online: \\
10 December 2020
\end{tabular}

\section{A B S T R A C T}

A field experiment was conducted in kharif-2019 at Agronomy Farm, Rajarshee Chhatrapati Shahu Maharaj College of Agriculture, Kolhapur. An experiment was laid out in randomized block design with three replications and seven treatments comprising five levels of zeolite $\left(60,80,100,120\right.$ and $\left.140 \mathrm{~kg} \mathrm{ha}^{-1}\right)$. The total uptake of $\mathrm{N}, \mathrm{P}, \mathrm{K}$ and micronutrients $(\mathrm{Fe}, \mathrm{Mn}, \mathrm{Zn}$ and $\mathrm{Cu})$ in paddy increased significantly due to zeolite application. Significantly the highest N $\left(66.97 \mathrm{~kg} \mathrm{ha}^{-1}\right), \mathrm{P}\left(20.17 \mathrm{~kg} \mathrm{ha}^{-1}\right), \mathrm{K}(67.57 \mathrm{~kg} \mathrm{ha}$ $\left.{ }^{1}\right)$ and micronutrients viz. Fe $\left(1790 \mathrm{~g} \mathrm{ha}^{-1}\right), \mathrm{Mn}\left(990 \mathrm{~g} \mathrm{ha}^{-1}\right), \mathrm{Zn}\left(155 \mathrm{~g} \mathrm{ha}^{-1}\right)$ and $\mathrm{Cu}(120 \mathrm{~g}$ $\mathrm{ha}^{-1}$ ) were recorded in treatment T7 (GRDF + Zeolite@ $\left.140 \mathrm{~kg} \mathrm{ha}^{-1}\right)$ and these were at par with the treatment T5 (GRDF + Zeolite @ $100 \mathrm{~kg} \mathrm{ha}^{-1}$ ) and T6 (GRDF + Zeolite @ $120 \mathrm{~kg}$ $\mathrm{ha}^{-1}$ ). The application of different levels of zeolite along with GRDF increased the N, P and $\mathrm{K}$ use efficiency of paddy. The highest nitrogen use efficiency (51.66 \%), phosphorus use efficiency $(53.80 \%)$ and potassium use efficiency $(96.25 \%)$ recorded in the treatment T7 (GRDF + Zeolite @ $\left.140 \mathrm{~kg} \mathrm{ha}^{-1}\right)$, but these values were at par with the values recorded in treatment T5 (GRDF + Zeolite @ $100 \mathrm{~kg} \mathrm{ha}^{-1}$ ) and T6 (GRDF + Zeolite @ $120 \mathrm{~kg} \mathrm{ha}^{-1}$ ). The results of the present investigation indicated that the application of zeolite @ $100 \mathrm{~kg}$ $\mathrm{ha}^{-1}$ along with GRDF was found effective in increasing nutrient uptake of paddy and nutrient use efficiency in soil.

\section{Introduction}

The zeolites are hydrated aluminosilicate minerals made from interlinked tetrahedral of alumina $\left(\mathrm{AlO}_{4}\right)$ and silica $\left(\mathrm{SiO}_{4}\right)$. The zeolites are composed of pores and corner sharing aluminosilicate $\left(\mathrm{AlO}_{4}\right.$ and $\left.\mathrm{SiO}_{4}\right)$ tetrahedrons, joined into 3 dimensional frameworks. The pore structure is characterized by cages approximately $12 \AA$ in diameter, which are interlinked through channels about $8 \AA$ in diameter, composed of rings of 12 linked tetrahedrons (Kaduk and Faber, 1995). The zeolite has an ability to gain or lose water reversibly, without the change of crystal structure. They could be used as fertilizers, stabilizers and natural chelates (PerezCaballero et al., 2008). The zeolite enables 
both inorganic and organic fertilizers to slowly release their nutrients (Perez-Caballero et al., 2008).

\section{Materials and Methods}

Field experiment was conducted in kharif2019 on sandy clay loam soil at Agronomy Farm, Rajarshee Chhatrapati Shahu Maharaj College of Agriculture, Kolhapur located at latitude of $16^{\circ} 42^{\prime}$ North and longitude $74^{0} 14^{\prime}$ East. The field experiment site climatically belongs to Sub-Montane zone of Maharashtra with an average rainfall of $1057 \mathrm{~mm}$, with 77 rainy days which are received mostly from south-west monsoon. Minimum and maximum mean temperature ranged from 11.83 to $20.9{ }^{0} \mathrm{C}$ and 24.9 to $33.1{ }^{0} \mathrm{C}$, respectively. The soil of experimental plot was alkaline in reaction ( $\mathrm{pH} 7.83)$, normal in electrical conductivity $\left(0.17 \mathrm{dS} \mathrm{m}^{-1}\right)$, moderately high in organic carbon content $(0.63 \%)$ and high in $\mathrm{CaCO}_{3}$ content $(9.86 \%)$, and have bulk density $1.27 \mathrm{~g} \mathrm{~cm}^{-3}$, CEC 16.91 cmol $(\mathrm{p}+) \mathrm{kg}^{-1}$. Soil was low in available nitrogen $\left(171.29 \mathrm{~kg} \mathrm{ha}{ }^{-1}\right)$, medium in available phosphorous (16.29 $\left.\mathrm{kg} \mathrm{ha}^{-1}\right)$ and high in available potassium (160.31 kg ha-1) content sufficient in available Fe $(4.52 \mathrm{mg}$ $\mathrm{kg}^{-1}$ ), available $\mathrm{Mn}\left(2.04 \mathrm{mg} \mathrm{kg}^{-1}\right)$, available $\mathrm{Zn}\left(1.54 \mathrm{mg} \mathrm{kg}^{-1}\right)$ and available $\mathrm{Cu}(1.63 \mathrm{mg}$ $\left.\mathrm{kg}^{-1}\right)$. The experiment was laid out in randomized block design with seven treatments and three replications. The treatments consisted of $\mathrm{T}_{1}$ : Absolute control, $\mathrm{T}_{2}$ : GRDF (100:50:50 kg ha ${ }^{-1} \mathrm{~N}: \mathrm{P}_{2} \mathrm{O}_{5}: \mathrm{K}_{2} \mathrm{O}+$ FYM 10 t ha $^{-1}$ ), T : GRDF+Zeolite @ $60 \mathrm{~kg}$ $\mathrm{ha}^{-1}, \mathrm{~T}_{4}$ : GRDF+Zeolite @ $80 \mathrm{~kg} \mathrm{ha}^{-1}, \mathrm{~T}_{5}$ : GRDF+Zeolite@100 kg ha ${ }^{-1}, \mathrm{~T}_{6}$ : GRDF+ Zeolite@120 kg ha ${ }^{-1}, \mathrm{~T}_{7}$ : GRDF+Zeolite @ $140 \mathrm{~kg} \mathrm{ha}^{-1}$.

The treatment wise application of zeolite and fertilizers mixture was done before sowing of paddy seed and covered with soil. The FYM was applied @ $10 \mathrm{t} \mathrm{ha}^{-1}$.The general recommended dose of fertilizer $(100 \mathrm{~kg} \mathrm{~N}+$
$50 \mathrm{~kg} \mathrm{P}_{2} \mathrm{O}_{5}+50 \mathrm{~kg} \mathrm{~K}_{2} \mathrm{O} \mathrm{ha}{ }^{-1}$ ) were applied per hectare at the time of sowing as per the treatments. The paddy variety Indrayani was sown by adopting standard package of practices. After the harvest rain and stover samples were collected separately, dried and powdered. The powdered $0.5 \mathrm{~g}$ plant samples was digested with concentrated $\mathrm{H}_{2} \mathrm{SO}_{4}(5 \mathrm{~mL})$ and $\mathrm{H}_{2} \mathrm{O}_{2}(5 \mathrm{~mL})$ digestion mixture $\left(\mathrm{CuSO}_{4}+\right.$ $\mathrm{K}_{2} \mathrm{SO}_{4}+$ selenium powder). The volume was made water to $100 \mathrm{~mL}$ after digestion of sample. A suitable aliquot was taken for nitrogen distillation and nitrogen was determined by Micro Kjeldahl method (Parkinson and Allen, 1975). The total phosphorous determined by using known quantity of triacid extract and the yellow colour was developed with combined $\mathrm{HNO}_{3}$ vanadomolybdate reagent. Phosphorous was determined colorimetrical by using spectrophotometer at $470 \mathrm{~nm}$ wavelength (Jackson, 1973). The total potassium was determined from known quantity of triacid digested extract by flame photometer (Chapman and Pratt, 1961). The plant samples (0.5 g each) were wet digested with nitric acid and perchloric acid. The volume was made to $100 \mathrm{~mL}$ with distilled water after digestion and was used for determination of micronutrient by using atomic absorption spectrophotometer (Zososki and Burau, 1977). The uptake of nutrients was calculated by multiplying dry matter with nutrient content.

\section{Results and Discussion}

The data pertaining to total uptake of N, P and $\mathrm{K}$ by paddy crop is presented in Table 1 . The data clearly indicated that there was significant increase in total uptake of $\mathrm{N}, \mathrm{P}$ and $\mathrm{K}$ with GRDF alone and in combinations with different levels of zeolite.

The significantly highest total $\mathrm{N}$ uptake of paddy $\left(66.97 \mathrm{~kg} \mathrm{ha}^{-1}\right)$ crop was recorded with the treatment $\mathrm{T}_{7}$ (GRDF+ Zeolite @ $140 \mathrm{~kg}$ 
$\mathrm{ha}^{-1}$ ), however it was at par with the treatment $\mathrm{T}_{5}$ (GRDF + Zeolite@100 kg ha ${ }^{-1}$ ) and $\mathrm{T}_{6}$ (GRDF + Zeolite@ $120 \mathrm{~kg} \mathrm{ha}^{-1}$. Similar trend was observed with total $\mathrm{P}$ and $\mathrm{K}$ uptake of paddy. The phosphorus uptake of paddy crop was significantly highest $\left(20.17 \mathrm{~kg} \mathrm{ha}^{-1}\right)$ with the treatment $\mathrm{T}_{7}(\mathrm{GRDF}+$ Zeolite @ $140 \mathrm{~kg}$ $\mathrm{ha}^{-1}$ ) but it was at par with $\mathrm{T}_{5}(\mathrm{GRDF}+$ Zeolite@100 kg ha ${ }^{-1}$ ) and $\mathrm{T}_{6}(\mathrm{GRDF}+$ Zeolite @ $120 \mathrm{~kg} \mathrm{ha}^{-1}$ ). The total K uptake of paddy was significantly highest (67.57 $\mathrm{kg} \mathrm{ha}{ }^{-1}$ ) with the treatment $\mathrm{T}_{7}$ (GRDF+ Zeolite@140 kg ha-1), however it was at par with $\mathrm{T}_{5}\left(\mathrm{GRDF}+\right.$ Zeolite @ $\left.100 \mathrm{~kg} \mathrm{ha}^{-1}\right)$ and $\mathrm{T}_{6}$ (GRDF + Zeolite@120 kg ha ${ }^{-1}$ ). The increase in total nutrient uptake of paddy crop registered due to combined effect of GRDF and with different zeolite levels is attributed to the unique character of zeolite that influenced soil CEC and in turn increased the $\mathrm{NH}_{4}{ }^{+}$absorption and decreased $\mathrm{N}$ loss induced by leaching. This increase in uptake of nitrogen may be due to the initial fixation of $\mathrm{NH}_{4}{ }^{+}$ions during nitrification of nitrogenous fertilizer and subsequent release and oxidation to nitrates which were made available for uptake by paddy. The zeolite possibly acted as an exchange fertilizer, with $\mathrm{Ca}^{2+}$ exchanging onto the zeolite in response to plant uptake of uptake of nutrient cations $\left(\mathrm{NH}_{4}{ }^{+}\right.$or $\left.\mathrm{K}^{+}\right)$. Similar beneficial effect of zeolite on increasing the availability and uptake of nutrients by different crops reported by Pickering et al., (2002), Ahmed et al., (2010) and Ozbahce et al., (2015).

The data pertaining to total uptake Fe, Mn, $\mathrm{Zn}$ and $\mathrm{Cu}$ by paddy as influenced by GRDF alone and in combination with different levels of zeolite presented in Table 2. The data clearly indicated that the total uptake $\mathrm{Fe}, \mathrm{Mn}$, $\mathrm{Zn}$ and $\mathrm{Cu}$ by paddy increased significantly with application of GRDF alone and in combination with different levels of zeolite. The significantly highest total uptake of $\mathrm{Fe}$ $\left(1790 \mathrm{~g} \mathrm{ha}^{-1}\right)$ by paddy was recorded with treatment $\mathrm{T}_{7}\left(\mathrm{GRDF}+\right.$ Zeolite @ $\left.140 \mathrm{~kg} \mathrm{ha}^{-1}\right)$ but it was at par with the treatment $\mathrm{T}_{5}$ (GRDF + Zeolite@100 kg ha ${ }^{-1}$ ) and $\mathrm{T}_{6}$ (GRDF + Zeolite@120 kg ha ${ }^{-1}$ ). The increase in total Fe uptake with zeolite application might be due to honeycomb like structure of zeolite entrapped cations and increases the iron uptake. The total Mn uptake of paddy crop was significantly highest $\left(990 \mathrm{~g} \mathrm{ha}^{-1}\right)$ with the treatment $\mathrm{T}_{7}\left(\mathrm{GRDF}+\right.$ Zeolite @ $\left.140 \mathrm{~kg} \mathrm{ha}^{-1}\right)$ but it was at par with the treatment $\mathrm{T}_{5}$ (GRDF + Zeolite@ $100 \mathrm{~kg} \mathrm{ha}^{-1}$ ) and $\mathrm{T}_{6}$ (GRDF + Zeolite@120 kg ha ${ }^{-1}$ ). Higher porosity of zeolite might have led to increase Mn uptake. The total $\mathrm{Zn}$ uptake of paddy was significantly highest $\left(155 \mathrm{~g} \mathrm{ha}^{-1}\right)$ with the treatment $\mathrm{T}_{7}\left(\mathrm{GRDF}+\right.$ Zeolite @ $\left.140 \mathrm{~kg} \mathrm{ha}^{-1}\right)$ but on par with $\mathrm{T}_{5}$ (GRDF + Zeolite @ $100 \mathrm{~kg}$ $\mathrm{ha}^{-1}$ ) and $\mathrm{T}_{6}\left(\mathrm{GRDF}+\right.$ Zeolite @ $120 \mathrm{~kg} \mathrm{ha}^{-1}$ ) which might be attributed to the ability of zeolite to hold nutrients and release as per the plant requirement. These results are in confirmity with those reported by Ozbahce $e t$ al., (2015). The treatment $\mathrm{T}_{7}$ (GRDF + Zeolite @ $140 \mathrm{~kg} \mathrm{ha}^{-1}$ ) recorded significantly highest uptake of total copper $\left(120 \mathrm{~g} \mathrm{ha}^{-1}\right)$ by paddy however it was at par with the treatment $\mathrm{T}_{5}$ (GRDF + Zeolite@100 kg ha ${ }^{-1}$ ) and $\mathrm{T}_{6}$ $\left(\right.$ GRDF + Zeolite @120 kg ha $\left.{ }^{-1}\right)$. The increase in total uptake of copper might be attributed to the properties of zeolite such as cation exchange capacity, adsorption capacity and porosity of zeolite which led to increase the micronutrient uptake. Similar results were also noticed by Ozbahce et al., (2015). Similar results were reported by Ozbahce $e t$ al., (2015).

The data pertaining to nutrient use efficiency are presented in Table 3 . The data clearly indicated that there was increase in $\mathrm{N}, \mathrm{P}$ and $\mathrm{K}$ use efficiency of paddy with increase in levels of zeolite along with GRDF. The highest $\mathrm{N}(51.66 \%), \mathrm{P}(53.80 \%)$ and $\mathrm{K}$ $(96.25 \%)$ use efficiency was found with treatment $\mathrm{T}_{7}\left(\mathrm{GRDF}+\right.$ Zeolite @ $140 \mathrm{~kg} \mathrm{ha}^{-1}$ ) followed by $\mathrm{T}_{6}, \mathrm{~T}_{5}, \mathrm{~T}_{4}$ and $\mathrm{T}_{3}$. 
Table.1 Total uptake of N, P and K by paddy as influenced by different levels of zeolite

\begin{tabular}{|c|c|c|c|c|}
\hline \multirow{2}{*}{$\begin{array}{l}\text { Tr. } \\
\text { No. }\end{array}$} & \multirow[t]{2}{*}{ Treatment details } & \multicolumn{3}{|c|}{ Total uptake of nutrients $\left(\mathrm{kg} \mathrm{ha}^{-1}\right)$} \\
\hline & & $\mathbf{N}$ & $\mathbf{P}$ & $\mathbf{K}$ \\
\hline $\mathbf{T}_{1}$ & Absolute control & 15.31 & 8.43 & 27.62 \\
\hline $\mathbf{T}_{2}$ & $\begin{array}{l}\text { GRDF (100:50:50 kg ha }{ }^{-1} \mathrm{~N}: \mathrm{P}_{2} \mathrm{O}_{5}: \mathrm{K}_{2} \mathrm{O} \\
\left.+ \text { FYM } 10 \mathrm{t} \mathrm{ha}^{-1}\right)\end{array}$ & 41.43 & 10.76 & 42.30 \\
\hline $\mathbf{T}_{\mathbf{3}}$ & GRDF+Zeolite@60 kg ha ${ }^{-1}$ & 48.15 & 12.68 & 48.69 \\
\hline $\mathbf{T}_{4}$ & GRDF+Zeolite @ $80 \mathrm{~kg} \mathrm{ha}^{-1}$ & 54.79 & 15.95 & 54.66 \\
\hline $\mathbf{T}_{5}$ & GRDF+Zeolite@100 kg ha ${ }^{-1}$ & 60.33 & 18.74 & 60.48 \\
\hline $\mathbf{T}_{6}$ & GRDF + Zeolite @ 120 kg ha $^{-1}$ & 63.64 & 19.03 & 64.89 \\
\hline $\mathbf{T}_{7}$ & GRDF + Zeolite @ $140 \mathrm{~kg} \mathrm{ha}^{-1}$ & 66.97 & 20.17 & 67.57 \\
\hline & SE \pm & 1.54 & 0.47 & 1.64 \\
\hline & CD (0.05) & 4.74 & 1.45 & 5.04 \\
\hline
\end{tabular}

Table.2 Total uptake of micronutrients by paddy as influenced by different levels of zeolite

\begin{tabular}{|c|c|c|c|c|c|}
\hline \multirow[t]{2}{*}{ Tr. No. } & \multirow[t]{2}{*}{ Treatment details } & \multicolumn{4}{|c|}{ Total uptake of micronutrients $\left(\mathrm{g} \mathrm{ha}^{-1}\right)$} \\
\hline & & $\mathbf{F e}$ & Mn & $\mathbf{Z n}$ & $\mathrm{Cu}$ \\
\hline $\mathbf{T}_{1}$ & Absolute control & 610 & 640 & 84 & 50 \\
\hline $\mathbf{T}_{2}$ & $\begin{array}{l}\text { GRDF }\left(100: 50: 50 \mathrm{~kg} \mathrm{ha}^{-1} \mathrm{~N}:\right. \\
\left.\mathrm{P}_{2} \mathrm{O}_{5}: \mathrm{K}_{2} \mathrm{O}+\mathrm{FYM} 10 \mathrm{t} \mathrm{ha}^{-1}\right)\end{array}$ & 1230 & 720 & 96 & 70 \\
\hline $\mathbf{T}_{\mathbf{3}}$ & GRDF+Zeolite@60 kg ha ${ }^{-1}$ & 1360 & 810 & 108 & 80 \\
\hline $\mathbf{T}_{4}$ & GRDF+ Zeolite @ 80 kg ha $^{-1}$ & 1530 & 890 & 120 & 90 \\
\hline $\mathbf{T}_{5}$ & GRDF+Zeolite@100 kg ha ${ }^{-1}$ & 1670 & 970 & 131 & 100 \\
\hline $\mathbf{T}_{6}$ & GRDF + Zeolite@120 kg ha ${ }^{-1}$ & 1710 & 980 & 140 & 110 \\
\hline $\mathbf{T}_{7}$ & GRDF + Zeolite @ $140 \mathrm{~kg} \mathrm{ha}^{-1}$ & 1790 & 990 & 155 & 120 \\
\hline & SE \pm & 0.04 & 0.03 & 0.003 & 0.003 \\
\hline & CD (0.05) & 0.13 & 0.08 & 0.01 & 0.01 \\
\hline
\end{tabular}


Table.3 Effect of different levels of zeolite application on nutrient use efficiency of paddy

\begin{tabular}{|c|c|c|c|c|}
\hline \multirow[t]{2}{*}{ Tr. No. } & \multirow[t]{2}{*}{ Treatment details } & \multicolumn{3}{|c|}{ Nutrient Use Efficiency (\%) } \\
\hline & & $\mathbf{N}$ & $\mathbf{P}$ & $\mathbf{K}$ \\
\hline $\mathbf{T}_{1}$ & Absolute control & - & - & - \\
\hline $\mathbf{T}_{2}$ & $\begin{array}{l}\text { GRDF (100:50:50 kg ha }{ }^{-1} \mathrm{~N}: \mathrm{P}_{2} \mathrm{O}_{5}: \\
\left.\mathrm{K}_{2} \mathrm{O}+\text { FYM } 10 \mathrm{t} \mathrm{ha}^{-1}\right)\end{array}$ & 26.12 & 10.68 & 35.37 \\
\hline $\mathbf{T}_{3}$ & GRDF+ Zeolite @ $60 \mathrm{~kg} \mathrm{ha}^{-1}$ & 32.84 & 19.47 & 50.76 \\
\hline $\mathbf{T}_{4}$ & GRDF+ Zeolite @ $80 \mathrm{~kg} \mathrm{ha}^{-1}$ & 39.48 & 34.46 & 65.15 \\
\hline $\mathbf{T}_{5}$ & GRDF+Zeolite@100 kg ha ${ }^{-1}$ & 45.02 & 47.24 & 79.16 \\
\hline $\mathbf{T}_{6}$ & GRDF + Zeolite @ 120 kg ha $^{-1}$ & 48.33 & 48.57 & 89.79 \\
\hline $\mathbf{T}_{7}$ & GRDF + Zeolite @ $140 \mathrm{~kg} \mathrm{ha}^{-1}$ & 51.66 & 53.80 & 96.25 \\
\hline
\end{tabular}

The higher nutrient use efficiency of paddy is attributed to the properties of zeolite such as high cation exchange, larger surface area, dehydration-rehydration and adsorption and slow release of nutrients during the growth of crop. The positive role of natural zeolite in reducing nitrogen leaching provides an opportunity for the crop to uptake more nitrogen and thus increases its grain yield. These could be related to enhance NUE at the presence of zeolite. These might be due to initial adsorption of $\mathrm{NH}_{4}{ }^{+}$during nitrification thereby retarding the nitrification rate and arresting the nitrogen losses. Increase in the use efficiency of added nitrogenous fertilizers due to steady release of $\mathrm{NH}_{4}{ }^{+}$ions resulted in constant nitrogen supply to the crop. Zeolite had capacity to adsorb phosphorus chemical fertilizer and reduce phosphorus from leakage in the soil. The calcium from the monocalcium phosphate (SSP) is adsorbed on the exchange sites of zeolite and the phosphate ions remains in the soil solution. It resulted into higher phosphorus use efficiency by increasing the absorption by paddy crop. These results are in confirmity with those reported by Hua et al., (2006), Kavoosi (2007) and Majid et al., (2012).

\section{References}

Ahmed, O. H., Sumalatha, G. and
NikMuhamad, A.M. (2010) Use of zeolite in maize (Zea mays) cultivation on nitrogen, potassium and phosphorus uptake and their use efficiency. International Journal of the Physical Sciences 5 (15), 2393-2401.

Chapman, H.D. and Pratt, P.F. (1961) Methods of analysis of soil, plant and water. Division of Agricultural Science, California University, USA 32, 14-19.

Hua, Q. X., Zhou J. M., Wang H.Y., Du C.W., Chen X. Q. and Li J. Y. (2006) Effects of modified clinoptilolite on phosphorus mobilisation and potassium or ammonium release in Ferrosols. Australian Journal of Soil Research 44, 285-290.

Jackson, M. L. (1973) Soil chemical analysis. Prentice Hall of India, New Delhi 24, 113.

Kaduk, J.A. and Faber, J. (1995) Crystal structure of zeolite as a function of ion exchange. RIGAKU Journal 12 (2), 1434.

Kavoosi, M. (2007) Effects of zeolite application on rice yield, nitrogen recovery and nitrogen use efficiency. Communications in Soil Science and Plant Analysis 38, 69-76.

Majid Aghaalikhani, Majid Gholamhoseini, Aria Dolatabadian, Aydin KhodaeiJoghan and Kamal Sadat Asilan (2012). 
Zeolite influences on nitrate leaching, nitrogen-use efficiency, yield and yield components of canola in sandy soil. Archives of Agronomy and Soil Science 58 (10), 1149-1169.

Ozbahce A., FuatTari,A., Erdal Gonulal, Necati Simsekli and Huseyin Padem (2015) Effect of zeolite applications on yield components and nutrient uptake of common bean underwater stress. Archives of Agronomy and Soil Science 61 (5), 615-626.

Perez-Caballero, R., Gil, J., Benitez, C. and Gonzalez, J.L. (2008) Effect of adding zeolite to soils in order to improve the $\mathrm{N}-\mathrm{K}$ nutrition of olive trees, preliminary results. American Journal of Agriculture Biological Science 2 (1),
321-324.

Parkinson, J. A. and Allen, S. E. (1975) A wet oxidation procedure suitable for the determination of nitrogen and other mineral nutrients in biological material. Communications in Soil Science and Plant Analysis 6, 7-11.

Pickering, H.W., Menzies, N.W. and Hunter, M.N. (2002) Zeolite rock phosphate-A novel slow release phosphorus fertilizer for potted plant production. Scientia Horticulture 94, 333-343.

Zososki, R.J. and Burau, R.G. (1977) A rapid nitric perchloric acid digestion method for multi- element tissue analysis. Communications in Soil Science and Plant Analysis 8 (5), 425-436.

\section{How to cite this article:}

Shinde, T. S., R. B. Pawar, A. V. Satpute and Shende, S. M. 2020. Effect of Zeolite on Nutrient Use Efficiency in Soil and Nutrient Uptake of Kharif Upland Paddy Grown on Inceptisol. Int.J.Curr.Microbiol.App.Sci. 9(12): 1803-1808. doi: https://doi.org/10.20546/ijcmas.2020.912.214 